199. 来迅通手の娄症について

$$
\begin{aligned}
& \text { 東海大学○村上 } \\
& \text { 䇣, 小宮山長太郎 } \\
& \text { 関 }
\end{aligned}
$$

（目的）柔道選手には他のスポーツ種目の選手にくら ベると腰痛を訴える者が多いといわれている，腰瘏を訴 えている殆どの趛手は，運動量の轻減，或は休養等によ り回復を待つが，腰痛発作の反復は競技出場を不可能と もし，関連した椎間板障害は椎間板へルニヤ，椎体の変 形および坐骨神程痛病歴を起こするとともなり得る。こ れら腰痛庭は，普段の不良姿勢や負荷の質と量などによ つてあ発症し，柔道練習時においての姿勢や技との関係 も見逃すことができない，そこで今回は腰痛应の原因を 把握し，よりよい柔道の指導に役立て度い（結果及ひ 考家）スポーツ種目による腰痛の頻度一東海大学，日 本体育大学，東京農業大学の 運動部員 (17 種目) 1081 名を対称として調查してみたところ，現在腰痛を訴えて いる者が柔道 $42 \%$ ，以下排球 $37 \%$ ，器械体操 $33 \%$ ，相 撗と籍球 30\%で，過去飞腰痛の 線匼ある者が陸上競挍 $51 \%$ ，ラグビー48\%，ハンドボールと野球 $46 \%$ と続く。 1081 名中これまで腰痡の経験ある者が 677 名 63\%あり，
そのうち柔道 $77 \%$ ，ラグビー，器㖑件操などが比校的高 率を示している。そしてこれらの腰痛の原因は種目によ つてその特質があるように思われる。

柔道選手の脊柱の偏倚と腰痛との関係一東海大学柔道 部の右技を得意とする 学生 45 名について背面からの写 真撮影し検討した結果，脊柱湖攀と判定されたのが73\% で，そのうち現在腰痛を訴えている者 $43 \%$ ，過去に腰 痛の経験のある者 $30 \%$ である．このことから脊柱の偏 倚と腰痛の間にはかなり深い関係があることがわかる。

脊柱の偏倚と技との関係一技を掛けた瞬間, 受けて一瞬 こらえた時の资柱の変化を写真撮影して検討した結果， 背負い投，体落しの場合は頸惟と胸惟の間で左に湾曲 し，続いて胸椎と腰椎の間で右に湾曲する複合性の変化 がみられ，内股，大外刈の場合は胸椎と腰椎の間で右に 湾曲する単純性の変化がみられるのが比較的多いといら ことが分つた（結ひ） 以上のことから柔道蒸手の腰痛 の原因は，一つには練習時に相手に技をかけた時つぶさ れ腰をひねつた時等と，一つは偏つた技による脊柱の偏 倚からくるものもあると思われる.
200. ハレーボールに阴する一考腺 (3)

一大举男女のゲーム㭢造の特性について一 都留文科大学○深瀨 吉邦, 一木 昭男 大阪体育大学 窲華高校 山本隆 久

1. 目的 本研究は6人制バレーボールのゲームを確 率論的立場から regular Markov chain を利用して分 析を試み，そのゲーム構造を明らかにしようとするすの である. 前 2 回の発表（基礎理論と分析範囲）に引き続 いて今回は大学男女のゲーム構造上の違いをゲーム傾向 とプレイの価值評価から比校考察した。

2. 対称 関東大学男子リーグ 1 部・NT大 $(41 \cdot$ 秋 リーク戦) 7 試合 $<$ 勝七ツト 15 , 負セット 12>, 同女子 リーグ1 部・TK 大 $(42 \cdot$ 春秋リーグ戦) 8 試合<勝七 ット 16 , 負セット $12>$.

\section{3. 教家の要的}

I ゲーム傾向の比較

（1）男女差の著しいプレイ（ゲーム構造上の相違点） $\delta<\% ;$ サーブ奻果率, サーブポイント率, レシーブ(A)

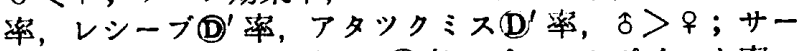
ブレシーブ成功率，ブロッ(A率、ブロックポイント率, アタック $\mathfrak{D}^{\prime}$ 率, アタツクヒツト率.

（2）勝ゲームと負ダームで著しく発現率が变化してい るプレイ (不安定な戦力), す;アタックA率, サーフ

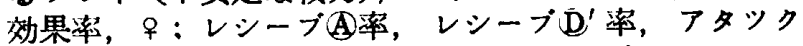
(A) 乷，アタックミス(A)率，サープポイント率。

(3) 上位チーム群との差が大きいプレイ（上位チーム

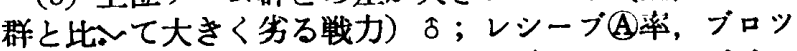

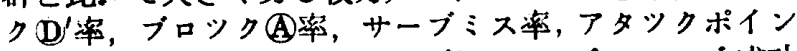

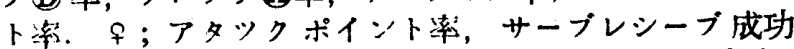

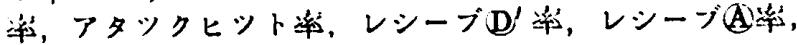

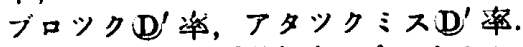

（4）発現率20\%以下のプレイは1本1本がゲームの勝
負に大きく影辢していると思われる（サーブボイント， サーブ効果（男子のみ）サーブミス，アタックミス(A),

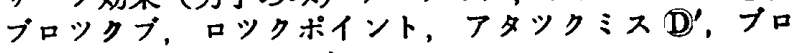
ック (D), プロクヒット).

I代人計算によるプレイの貢献度評価

各プレイを10 100\% 增減したと仮定して（他のプレ イの発現率は不変として) 計算し,プレイ1本について の価值 (平均值) を算出してブレイのゲームへの頁献度 指数とした.これによつてプイヤーの評価や強化目標の

\begin{tabular}{|c|c|c|c|c|c|}
\hline ay & 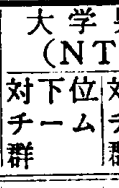 & 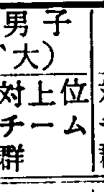 & 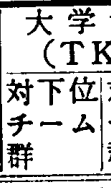 & \begin{tabular}{l|} 
女子 \\
K大) \\
凉上位 \\
チ-ム \\
群 \\
\end{tabular} & 毞 考 \\
\hline Serv & 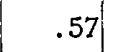 & 6 & 43 & .67 & $a_{2} \rightarrow a_{1}$ \\
\hline IV & & & & a & \\
\hline पiss & -.43 & -.33 & -.57 & -.33 & $a_{3} \rightarrow a_{2}$ \\
\hline int & .50 & .61 & .37 & .61 & $\mathrm{c}_{2} \rightarrow \mathrm{c}_{1}$ \\
\hline (A) & & & 1 & 0 & \\
\hline Miss (A) & -.44 & -.34 & -.59 & -.34 & $c_{3} \rightarrow c_{2}$ \\
\hline $\begin{array}{r}\text { Servereceive } \\
\text { Mi }\end{array}$ & & & -.62 & -.54 & $d g^{\prime} \rightarrow \mathrm{d}$ \\
\hline ttack-hit & .41 & .53 & .36 & .46 & $c_{2}^{\prime} \rightarrow c_{1}^{\prime}$ \\
\hline 1 & & & & & \\
\hline
\end{tabular}
設定が容易になると思わ机る。

\section{ブレイのゲーム貢献度指数}

